\title{
開放性砂浜海岸の港湾周辺域におけるウバガイ分布特性と物理環境に関する研究
}

Characteristics of the distribution of surf clam and physical environment around port in open sandy beach

渥美洋一*。石澤健志**.國田淳 ${ }^{* *}$. 谷野賢二***. 明田定満****

鳴海日出人*****. 中村義治 $* * * * * *$. 山下俊彦*******

Youichi Atsumi,Takeshi Ishizawa, Atsushi Kunita,Kenji Yano, Sadamitsu Aketa, Hideto Narumi, Yoshiharu Nakamura, Toshihiko yamashita

Surf clam Pseudcardium sybillae which lives in sandy beaches along the open sea is important fishery resources at Tomakomai coast. Characteristics of the distribution and the growth of the clam around harbor structures are studied from field observation. Environments of food and sediment for the clam are investigated. It was found that the population of young $\mathrm{clam}$ increased around Tomakomai-port by its accumulation effects. keywords : surf clam, field observation, harbor structure

1.はじめに

近年の生物多様性・生態系に配慮した沿岸域・海洋域の環境保全に対する要請が高まる中で、港湾建設等の開 発行為が生態系にどの様な影響を及ぼすかを評価するためには、生態系環境調査の技術を確立することが必要不 可欠となっている。苫小牧港東港区は、開放性砂浜海域である苫小牧港海域に建設された大規模掘込港湾であり、 建設以前から現在に至るまでの海洋生物を含む多項目の環境調查データが蓄積されている。

そこで、本研究では生態系環境調査技術の確立を目指し、当海域における代表的な有用種であり、かつ構造物 建設に伴う環境影響に対して指標性が高いとされるウバガイ稚貝を対象とし、現地調査を実施した。現地調査に ついては、稚貝の個体数分布、及び成長状況の調査とあわせて、生息場環境・物理環境調査を実施し、港湾構造 物建設による環境勾配の変化が稚貝の資源量に与える影響を明らかにすることに留意した。

\section{2. 研究内容}

ウバガイは、別名ホッキガイとも呼ばれる、潜砂性二枚貝の一種である。北海道では6〜8月にかけて産卵し、 1 ヶ月程度の浮遊幼生期間を経て海底に着底する。以降は底生稚貝期に入るが、この期間に激しい減耗を受け、 満1柃に達するまでに、着底直後の約 $99 \%$ 以が死亡すると推定されている。今回このウバガイについては、 浮遊生物生息場の水理環境を、現地観測により的確に把握するのは困難であるため、「浮遊幼生期」は対象とせ ず、着底以降の「底生稚貝期」を対象とする。

ウバガイ稚貝の生態系環境調査は、構造物近傍か亱かの差異を考慮し、海域に岸沖方向の 3 測線を設置する。 さらに、水深帯による差異も考慮するため、各測線で水深- $2 \mathrm{~m} \sim-15 \mathrm{~m}$ の、各水深毎 14 点の調査を行った。

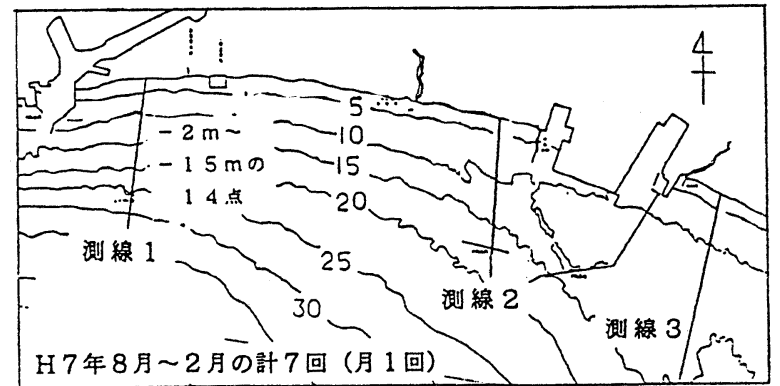

図一1 1 7 7 年度調査位置図

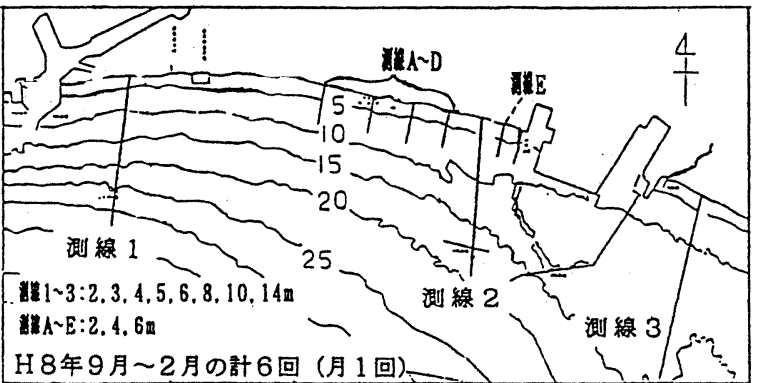

図一2 $\mathrm{H} 8$ 年度調查位置図

\footnotetext{
* 正会員 北海道開発局室闌開発建設部苫小牧湾建設事務所（053 苫小牧市末広町1丁目 1 番 1 号）

** 北海道開発局室闌開発建設部苫小牧湾建設事務所

*** 正会員北海道開発局開発土木研究所環境水工部水産土木研究室

***** 北海道開発局開発土木研究所環境水工部港湾研究室

***** 正会員日本データーサービス株式会社

$* * * * * *$ 水産庁中央水産研究所

$* * * * * *$ 正会員北海道大学大学院工学研究科
} 
主要な調査項目は以下の 2 点である。

(1)個体数分布・成長状況…稚貝の出現個体数・重量・殼長

(2)貝の生息環境…‥直上水の水質（クロロフィルa，SS）、底質分析（粒度組成，クロロフィルa）、ベントス（優占上位 3 種）

以上の各調查は、時系列な変動も踏まえた、環境特性を把握するため、H 7 年度については、H 7 年 8 月から $H 8$ 年 2 月までの計 7 回、H 8 年度については、H 8 年 9 月からH9 年 2 月までの計 6 回行った。

\section{3. 現地観測結果}

\section{3-1 底質環境の解析結果}

H 7 年度における測線 1 〜 の各地点での「粒径分布図」を図ー 3 に示す。この粒径の調査方法は、 1 地点 1 本、透明塩化ビニル管を $20 \mathrm{~cm}$ 海底面に打ち込み、水中で密封してコア採取する。その後、試験室にて冷凍保 存し、ドライアイスで完全凍結後、深さ方向に $2 \mathrm{~cm}$ 間隔でコアを切断し、層別に含水試験等の分析試験を行う ものである。底質中のクロロフィルa、シルト含有率の経時変化を図ー4〜6に示す。測線 1 では、粒径 0.0 $6 \mathrm{~mm} \sim 0.25 \mathrm{~mm}$ の細砂が中心で比較的淘汰の良く、図ー5よりシルトの变化量も極めて少ない海域といえ る。測線 2 も細砂が中心であるが、 $-5 \mathrm{~m}$ から徐々にシルト分が増加し、最大となる- $15 \mathrm{~m}$ 地点では、2 $5 \%$ 以上となる。測線 3 は測線 2 と同様に $-5 \mathrm{~m}$ からシルト分が増加しているが、 $-14 \mathrm{~m}$ 地点からは、磞分が多い 分布となっている。また、二枚貝の餌料となるクロロフィルaの含有量と、シルト分の相関は図ー6に示すよう に低くなっている。

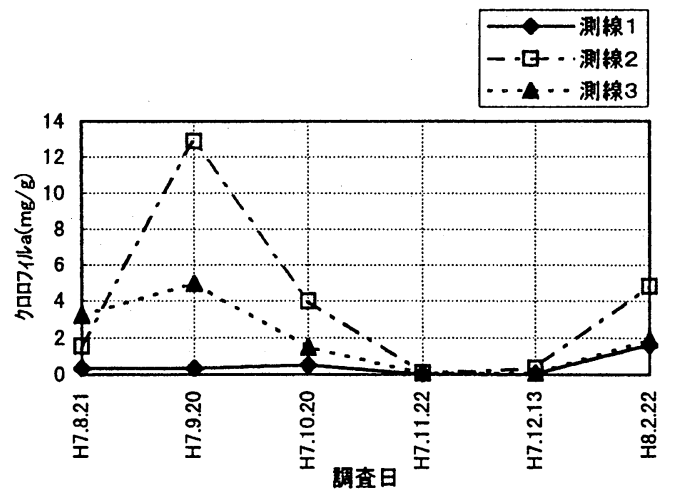

図-4 底質中のクロロフィル a 含有量 経時变化図

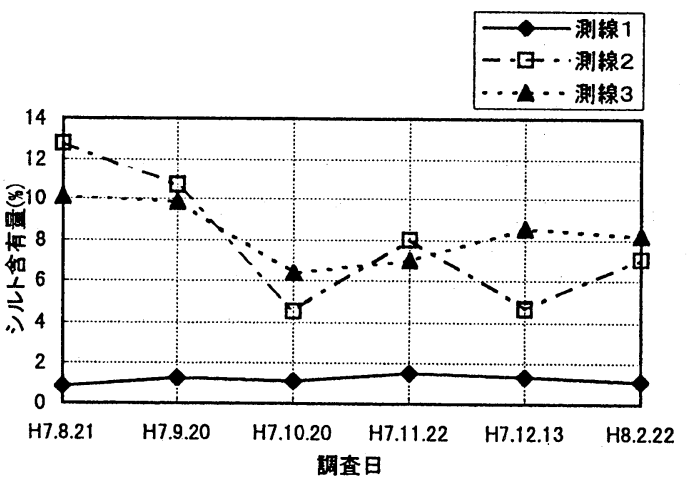

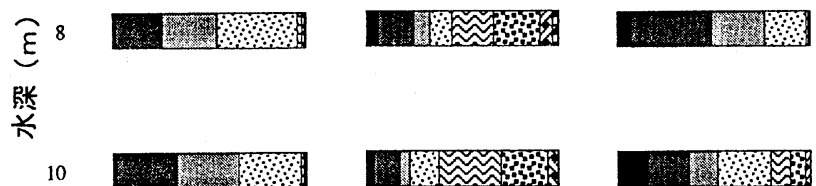
$\begin{array}{llllllllllllll}25 & 50 & 75 & 100 & 0 & 25 & 50 & 75 & 100 & 0 & 25 & 50 & 75 & 100\end{array}$ 粒径 $(\mathrm{mm})$

測線 3
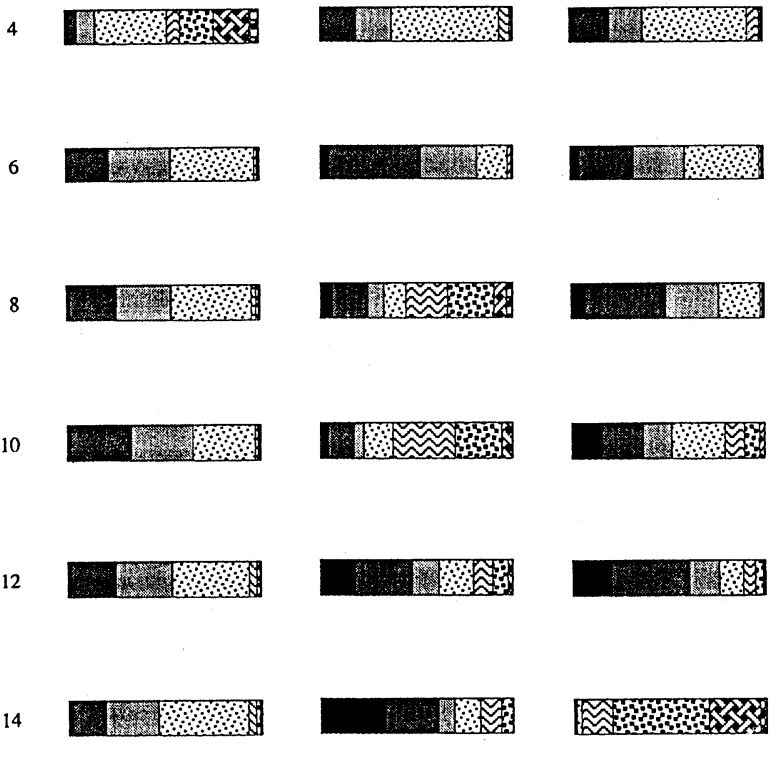

15
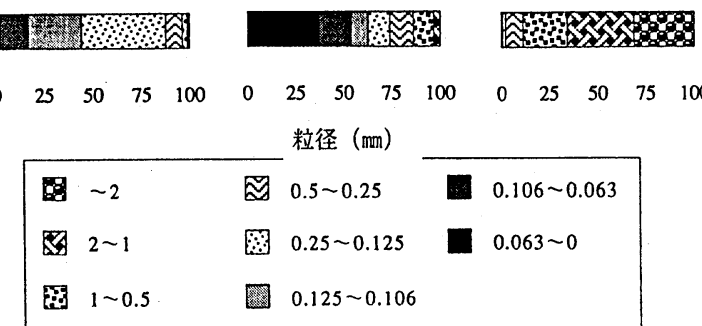

図一－＼cjkstart底質粒径分布図

\section{몰}

図一 5 底質中のシルト含有率経時変化図

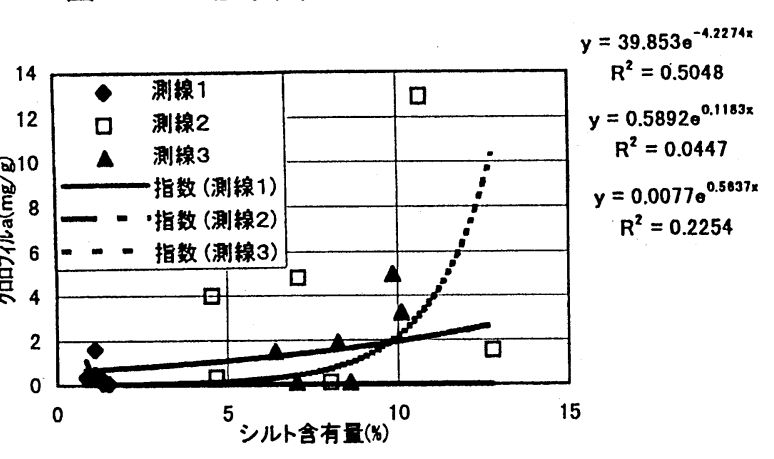

図-6 底質中のシルト含有量と クロロフィル a 相関図 
$3-2$ ベントス調查結果

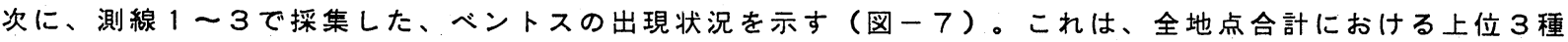
及び、各測線の優占種 1 種にウバガイを追加したものである。前出の図ー3と対比すると、測線 1 ではシルト分

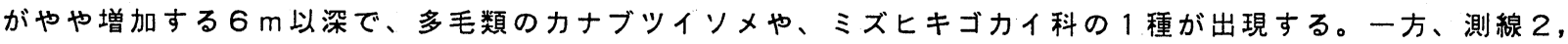
3 では全水深帯にシルト分がみられることから、ー2 - $4 \mathrm{~m}$ 付近から多毛類が出現し、優占率も高くなってい る。
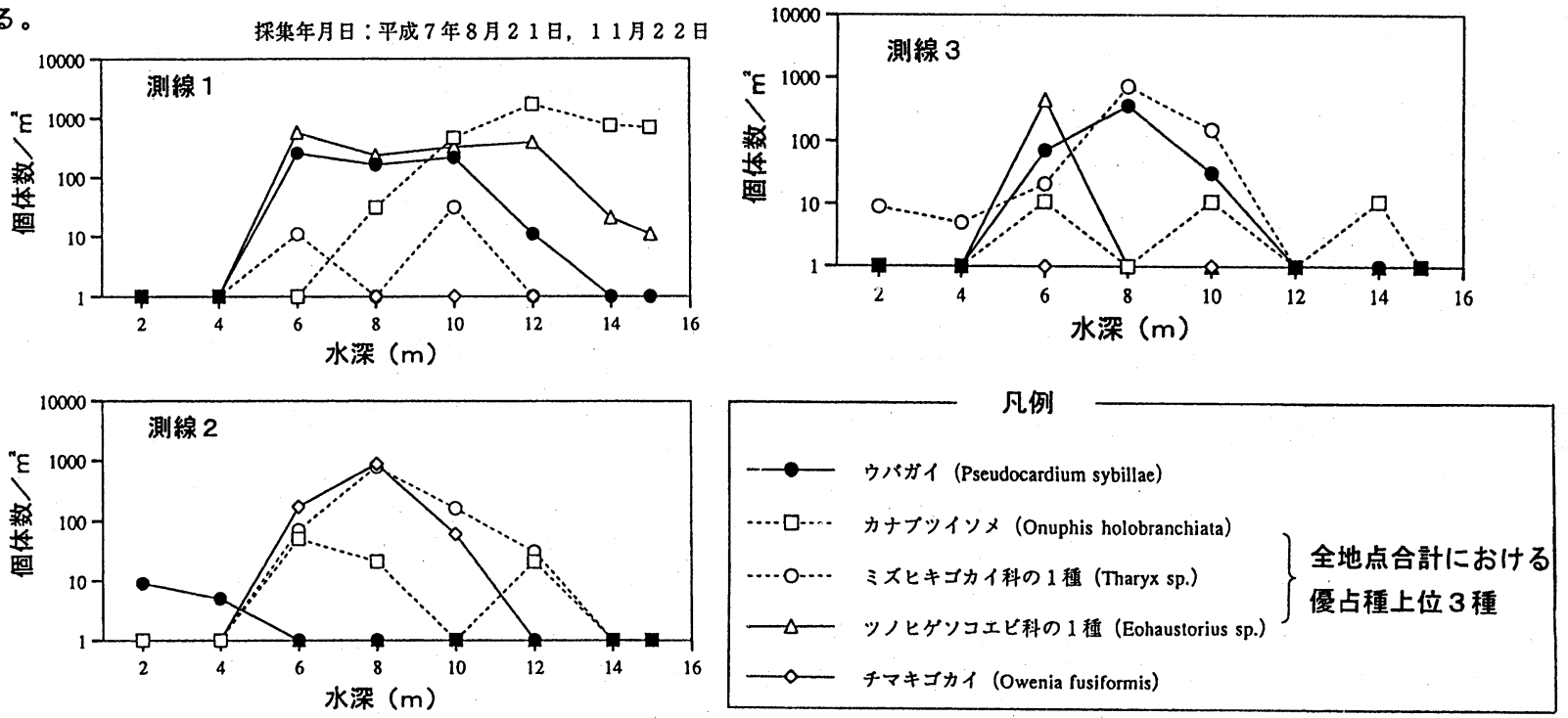

図ー7ベントス優占率の出現状況図

優占種は、カナブッイソメ、ついでミズヒキゴカイ科の 1 種(Tharyx sp.)と、ッノヒゲソコエビであり、ウバ ガイは 6 番目であった。また、チヨノハナガイ、ミズヒキゴカイといった、いわゆる污染指標種と呼ばれるもの

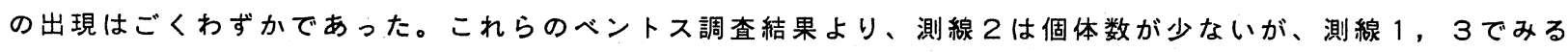
限り、ウバガイが苫小牧港海域のマクロベントスとしての指標性を持つことが考えられる。

\section{3-3 水質及び餌料環境調査結果}

H 7 年 8 月, 11 月のS S 鉛直分布を、図ー9に示す。 S S 量の挙動は、波による海底面からの巻き上げや、ご く沿岸域では河川から流入する淡水の影響により様々に 変化する。ウバガイ等の二枚貝類に代表される濾過食者 にとっては、摂餌時に濾水量の低下を生じさせる、成長 疎外要因ともなる。

中村ら”に基づき、苫小牧港海域のウバガイ餌料環境

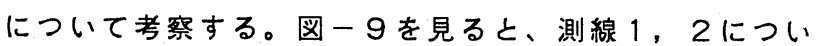
ては水深帯ごとの大幅な变化は見られないが、測線 $3 に$ おいて水深-2- - 8 mの地点で、一悌にS S 量の多い 調査結果となった。これは測線 3 の位置が、苫小牧港東 港区東防波堤の外側に設定されているため、厚真川から の河川水流出等が影響しているものと考えられる。また、 図ー8からも水温とクロロフィルaの相関が極めて高い ことがわかる。

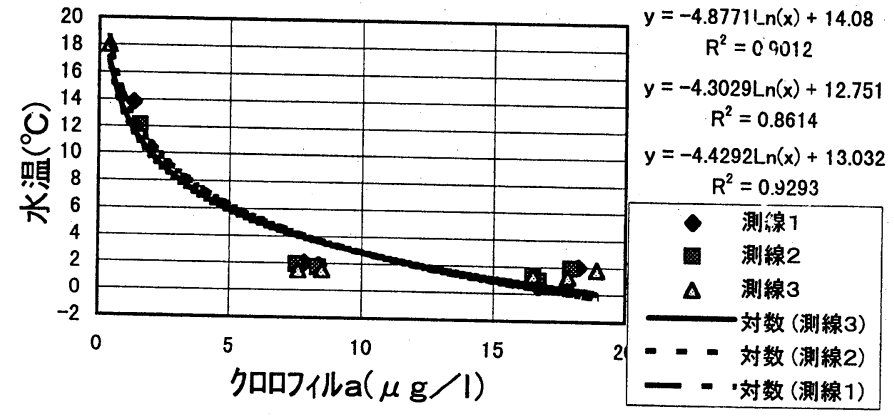

図一8 水温一クロロフィルa相関図
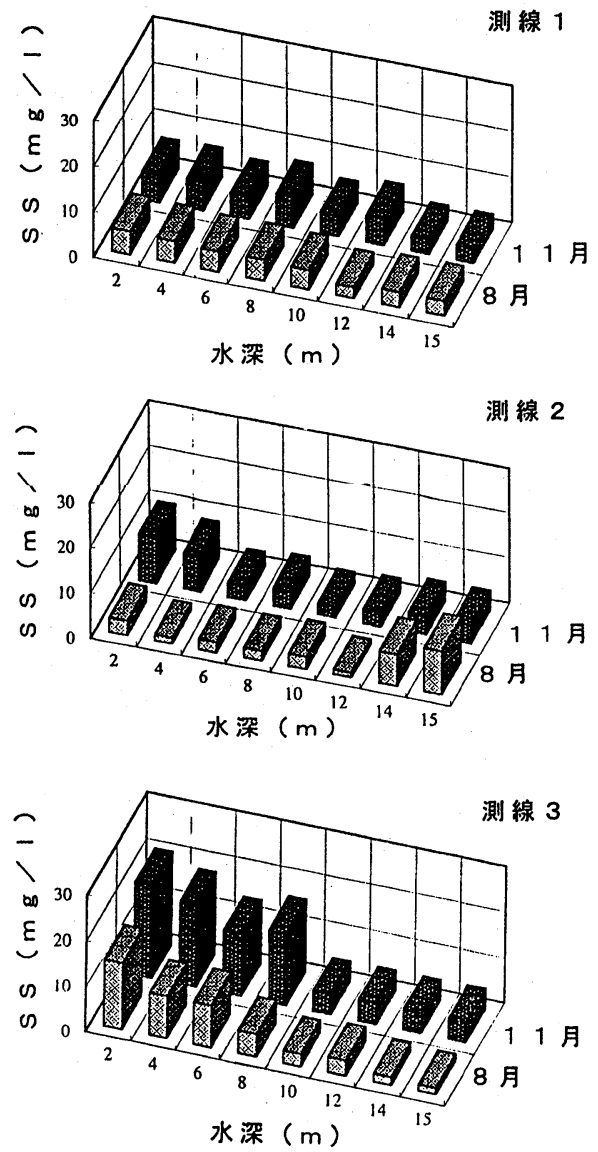

図一9 海底直上水中の S S 量变化図 
次に、直上水の餌料環境指数と、水温との関係を図ー10に示す。水中に存在するクロロフィルaの量は、植物 プランクトンの現在量を表すと同時に、捕食者であるウバガイ等の二枚貝類の餌としても重要である。クロロフ ィルaの分解産物であるフェオフィチン(PheoPigment)は、生物活動の結果であり、クロロフィルaよりは餌と しての質は劣る。これら 2 者の合計 (Total Pigment)に 対するクロロフィルa量の 比 ( $\mathrm{CH}$ l.a/Total Pigment $=\mathrm{C}$ /P比)、あるいは $S S$ 量に対 するクロロフィルa量の比 は、海域の餌料環境を示す 指数として、二枚貝の、主 に成長に大きく関わってく るものである。図から、8 月〜 11 月にかけて水温の 低下と共に、C/Pの量は 若干高くなっている。
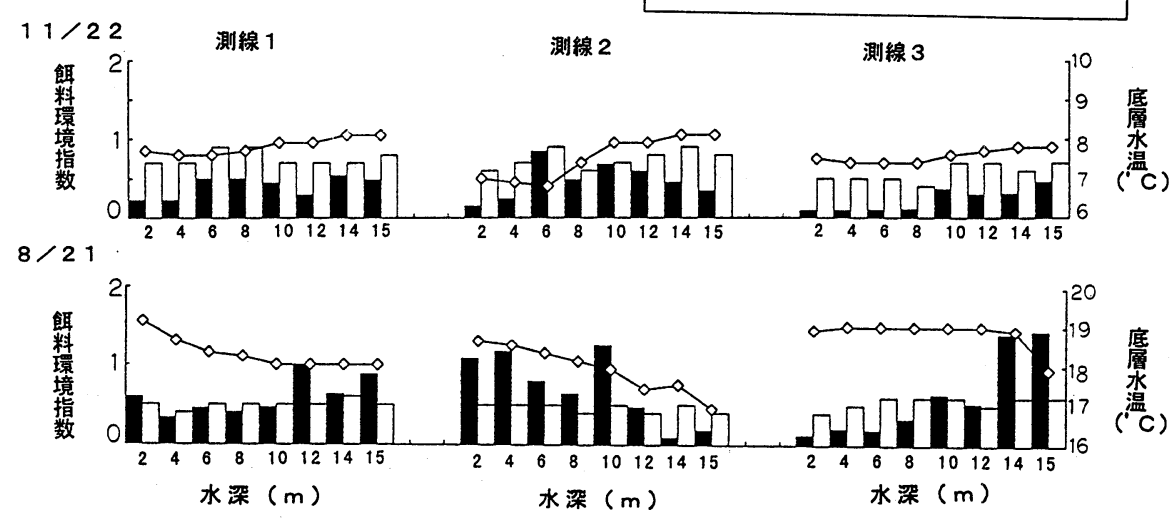

図一 10 直上水中の餌料環境指数と水温

3-4 ウバガイ、サラガイ、バカガイの個体数密度分布

ウバガイ稚貝の出現状況を、H７年度とＨ８年度とで比較して示す。（図ー11, 12）
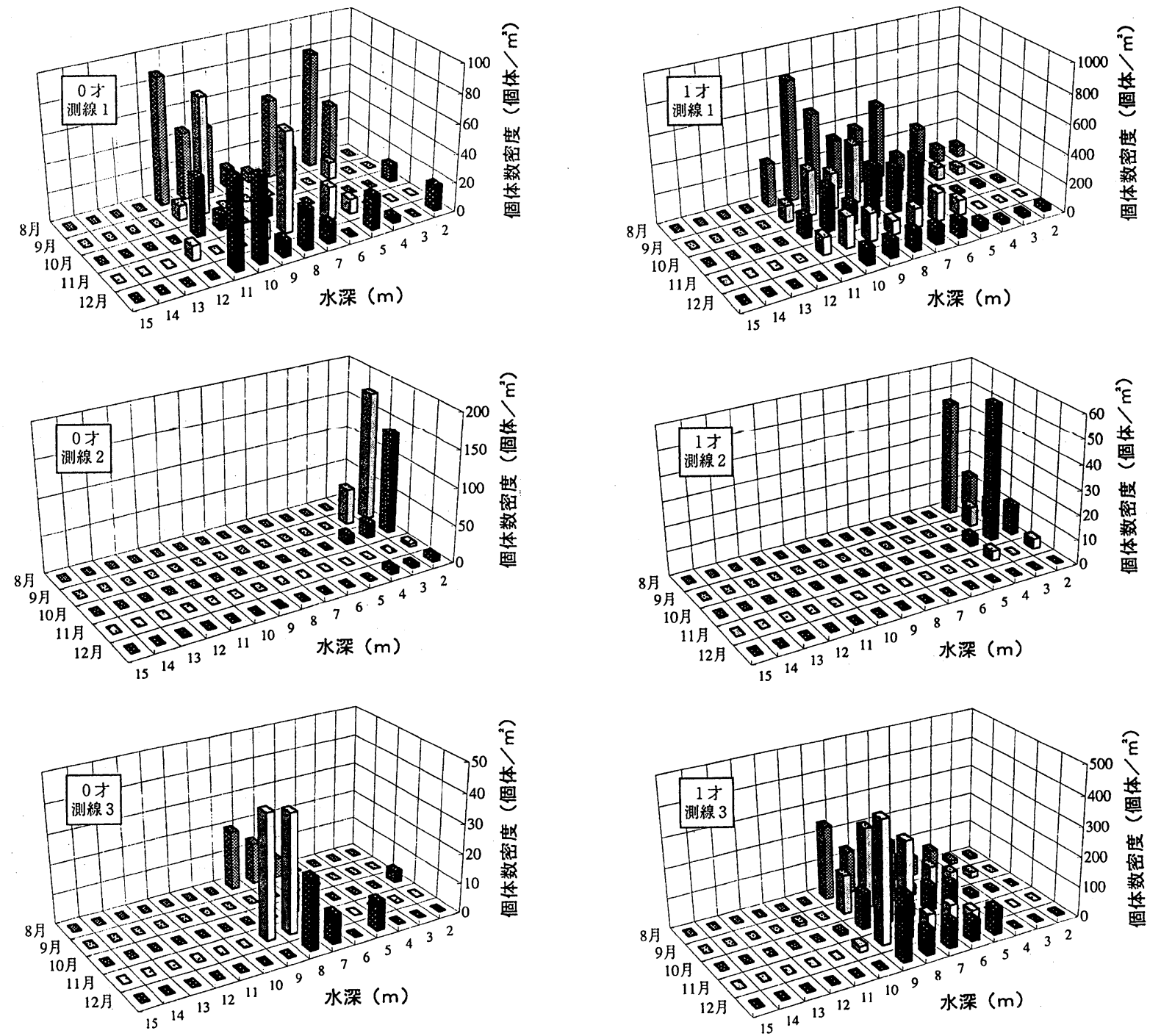

( 0 歳貝)

図ー11 H7 年度ウバガイ稚貝出現状況図

( 1 歳貝) 
測線 1

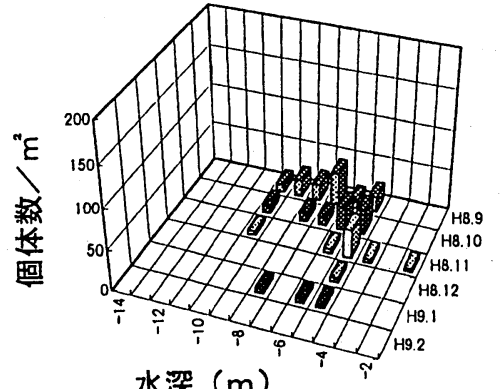

水深 $(\mathrm{m})$
測線 2

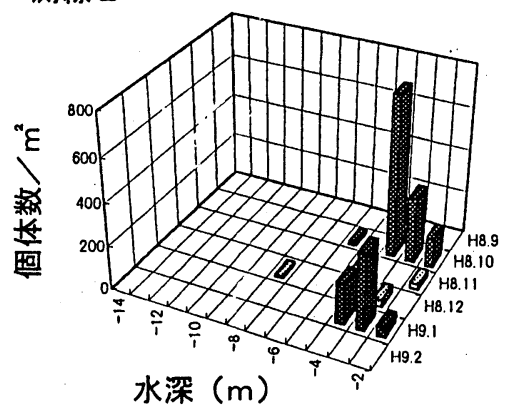

測線 3

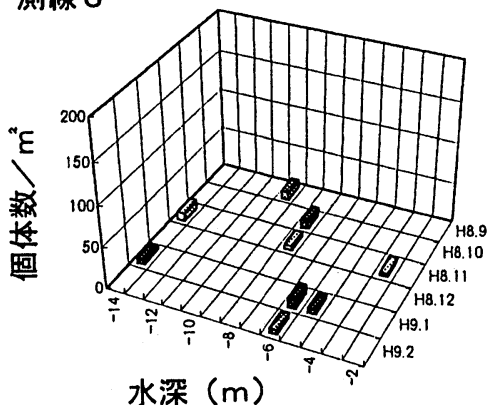

图一12 H8 年度ウバガイ稚貝出現状況図( 0 荿貝)

図ー11，12をみると、H 7 年度は測線 1 に稚貝が多く出現していることが分かる。その反面、構造物近傍の測 線 2 では、水深-2 - - $4 \mathrm{~m}$ 付近を除き、非常に資源量が少ない。しかしH 8 年度においては測線 2 の出現数が 最も多くなっており、このことから、H 7 年度による測線 1 の資源量分布が、必ずしも通年の資源分布の特性を 代表するものではないことがわかる。H 7 年度において、測線 $1 ， 3$ を比較すると、測線 3 での稚貝の生残率が 極めて高くなっている。これは位置的に東港東防波堤の背後に位置し、波浪の減衰による打ち上げ防止と、周辺 からの移入によるものと推察される。さらにH8 年 10 月に測線 2 の付近で大量発生していた稚貝は、1 1 月に なり急に個体数が減少している。これは、H 8 年 10 月 23 日頃からの時化により、減耗あるいは離散したもの と思われる。次に、H 7 年度にウバガイと同時に採取した、バカガイ, サラガイの最も個体数の多かった測線 3 における、○歲貝と1歳貝を合計した経時的な個体数密度を困ー13に示す。この図から、バカガイ、サラガイは

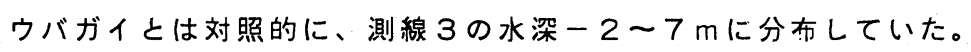
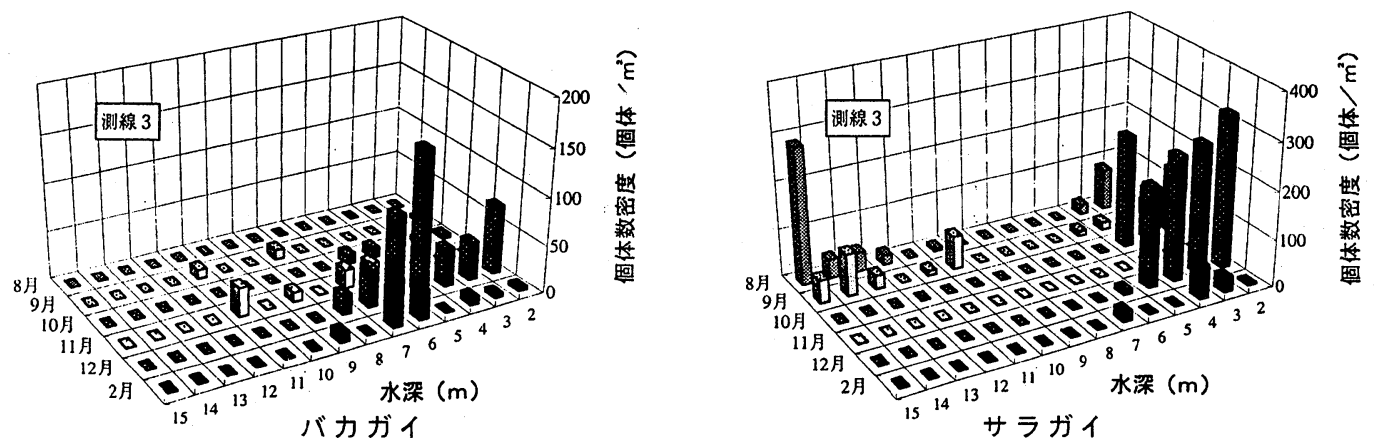

図ー13 H 7 年度バカガイ、サラガイの出現状況図（０歳貝＋1歳貝,測線 3)

3-5 個体群の変動 (減耗, 移動)

一般に魚貝類等の個体群の変動は、指数関数的に減少することが知られており、その個体数の減耗過程は、

$$
\begin{array}{ll}
N \mathrm{t}=\mathrm{N} \circ \mathrm{e}^{-M t} \quad \mathrm{t}: \text { 時間 } \quad N \mathrm{t} \text { : 時間 } \mathrm{t} \text { における個体数 } \quad N o \text { : 時間 } \mathrm{t}=\mathrm{O} \text { における個体数 } \\
M \text { : 全減少係数 }
\end{array}
$$

であり、生残率 $S$ は、 $\mathrm{s}=\mathrm{e}^{-\mathrm{M}}$

となる。普通全減少係数は、自然死亡係数 $\mathrm{M}$ と漁獲による死亡係数 $\mathrm{F}$ をした Z で表されるが、ウバガイ稚貝で は、自然死亡三全死亡となるので減少係数をMとして扱った。

算出された、H 7 年度の地点別ウバガイ稚貝の減耗過程を、図ー14に示す。この図を見る限りでは、測線 3 の 当歳貝は增加傾向を示す結果となっている。これは、採取個体数の少なさに加え、9月以降続けて加入する群や、 周辺海域から移入してくる群の影響を除去できなかったためと考えられる。
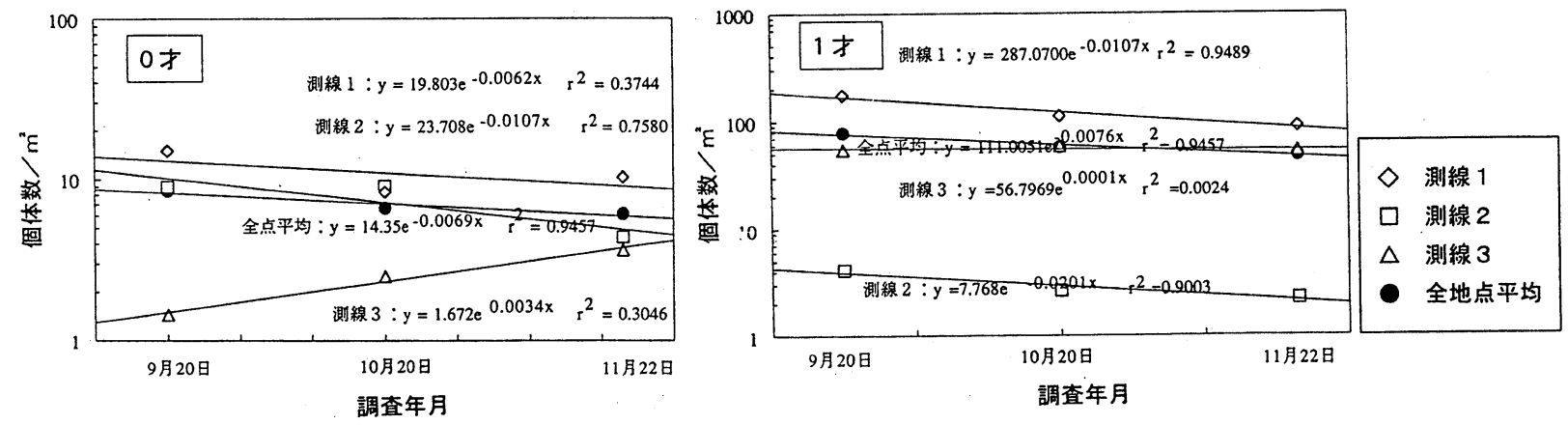

図ー14 各測線におけるウバガイ稚貝の減耗過程 


\section{4. 主要な検討結果}

平成 7,8 年度の 2 年を通じて実施した、現地調査データの解析に基づき、苫小牧港海域のウバガイ稚貝に 関する、構造物周辺域の資源分布特性、及び生息環境特性について以下に主要な結論をのべる

（1）水温とクロロフィルaを同時に観測することにより、水温一海底直上水中のクロロフィルaの相関式：y を示した。 $y=-4.4292 \operatorname{Ln}(X)+13.032$

(2) 本調查での、クロロフィルaとS Sの相関は低い。

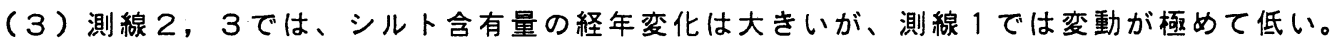

(4) 底質中のシルト含有率と、クロロフィルaの相関は、極めて低い。

(5) H 7 年度の稚貝個体分布については、ウバガイは測線 1，3、ウバガイより採取試料数の多い、バカガイ，

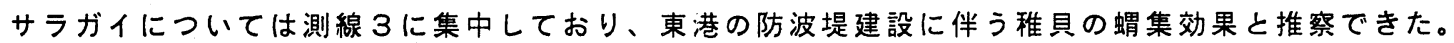

\section{あとがき}

今回の現地観測、及び解析結果により、ウバガイ稚貝の苫小牧港海域の生息環境特性、底質環境とベントス優 占種の分布、水質、及び底質の餌料環境、及びウバガイを中心とした、二枚貝の資源变動を明らかにした。また、 これらの基礎データより、ウバガイ稚貝の成長及び、減耗過程について考察を行った。このうち、特に減耗につ いては、自然死亡、波浪・流れによる減耗、餌料不足による減耗、さらには打ち上げによる減耗など、様々な減 耗要因が考えられ、それらについて各要因別に減耗量を推定するのは、現段階では非常に困難である。この減耗 要因別の調査については、生態工学の面からの適切な現地調查、及び解析手法の確立が必要と考えられる。また、 現在日本風土に適合した、ミチゲーション技術についての討論が盛んであり、この視点から見れば、海洋構造物 の持つ水産生物保全・増殖効果を、本調査のような生態系調查によるデータ蓄積により、適切に評価すると共に、 水産生物保全・增殖効果から見た、波浪・流況・底貎の最適制御技術として、生態系モデルによる、海洋構造物 建設効果を予測評価する技術の検討が必要不可欠であると考えられる。

\section{5. 参考文献}

1) 中村義治, 田口哲, 飯泉仁, 三村信男, 村井克詞 (1995): 二枚貝の餌量環境亡資源变動モデルに関する一考察, 水産土木 Vol.42 pp1121-1125

2) 山下俊彦 (1995): 波浪による二枚貝の挙動と漂砂, 土木学会 第31回水工学に関する夏期講習会講義集B-8$1 \sim B-8-13$

3）明田定満，宮本義憲，谷野賢二，佐藤仁，桑原伸司(1993):防波堤延長に伴うホッキガイ分布域の変遷一石狩 湾新港を事例としてー，土木学会、海岸工学講演会論文集 Vol.42 pp1156-1160

4 ) 武内智行 (1995):沿岸域における生態環境技術の動向, 水工学シリーズ 95-B-7

5 ) 日向野純也，安永義暢 (1993):開放性砂浜域における海底地形変化と二枚貝の分布性状について, 海講論文集 $767-771$ 